\title{
Cooking impact in color, pigments and volatile composition of grapevine leaves (Vitis vinifera L. var. Malvasia Fina and Touriga Franca)
}

\author{
Adriano Lima ${ }^{\mathrm{a}, \mathrm{b}}$, José Alberto Pereira ${ }^{\mathrm{c}}$, Ilton Baraldi ${ }^{\mathrm{b}}$, Ricardo Malheiro ${ }^{\mathrm{c}, *}$ \\ ${ }^{a}$ School of Agriculture, Polytechnic Institute of Bragança, Campus de Santa Apolónia, 5300-253 Bragança, Portugal \\ ${ }^{\mathrm{b}}$ Universidade Tecnológica Federal do Paraná, Campus Medianeira, Avenida Brasil, 4232, Bairro Independência, CEP 85884-000 Medianeira, Paraná, Brazil \\ ${ }^{\mathrm{c}}$ REQUIMTE/LAQV, School of Agriculture, Polytechnic Institute of Bragança, Campus de Santa Apolónia, 5300-253 Bragança, Portugal
}

\section{A R T I C L E I N F O}

\section{Article history:}

Received 10 August 2016

Received in revised form 7 November 2016

Accepted 7 November 2016

Available online 9 November 2016

\section{Keywords:}

Grapevine leaves

Blanching

Boiling

Composition

Volatile profile

\begin{abstract}
A B S T R A C T
Grapevine leaves (Vitis vinifera L. var. Malvasia Fina and Touriga Franca) under culinary treatment (blanching and boiling at 60,75 and $90 \mathrm{~min}$ ) were studied for their color, pigments and volatile fraction changes.

Blanching and boiling caused a decrease in luminosity and a loss of green coloration in both varieties, while a yellow-brownish color arose. Significant correlations were established between the loss of green color (monochromatic variable $a^{*}$ ) and the total chlorophylls content. The main volatiles in fresh leaves $[(Z)$-3-hexenal, $(Z)-3$-hexen-1-ol, and (Z)-3-hexenyl acetate] were drastically reduced by blanching and suppressed by boiling. Other compounds like pentanal and 6-methyl-5-hepten-2 one arose from blanching and boiling.

A boiling time of $60 \mathrm{~min}$ is adequate for the culinary process of grapevine leaves, since the product is considered edible and the pigments and volatile changes are not as drastic as observed at 75 and 90 min of boiling.
\end{abstract}

(c) 2016 Elsevier Ltd. All rights reserved.

\section{Introduction}

Grapevine leaves (Vitis vinifera L.) are considered a sub-product of the wine making industry and are treated as such (Teixeira et al., 2014), while in other countries (mainly in Turkey, Greece and Middle East countries), they are used as an ingredient for the preparation of dishes (Sat, Sengul, \& Keles, 2002), being Sarma one of the most popular ones (grapevine leaves rolled around vegetables and minced meat). Grapevine leaves can be consumed fresh or in preserved forms (frozen or in brine solutions and preserved in cans or jars) (Sat et al., 2002). Nevertheless, in order to become edible, they are processed by culinary treatments (blanching, boiling or steaming) (Sat et al., 2002). The changes undertaken during processing treatments are well described for several vegetables regarding antioxidant properties (Adebooye, Vijayalakshmi, \& Singh, 2008), mineral content (Kawashima \& Soares, 2003; Kumari, Gupta, Lakshmi, \& Prakash, 2004), nutritional value (Miglio, Chiavaro, Visconti, Fogliano, \& Pellegrini, 2008), and bioactive components (Negi \& Roy, 2000). Nevertheless, information concerning grapevine leaves changes during the culinary and preservation processes is very limited. One of the few records is

\footnotetext{
* Corresponding author.

E-mail address: rmalheiro@ipb.pt (R. Malheiro).
}

from Sat et al. (2002), who studied the impact of blanching for the preservation and suitability of Turkish varieties of grapevine leaves. These authors demonstrated that the blanching treatment considerably influences the color parameters and the sensory perception of panelists, also noticing that grapevine variety is also an important parameter. Some varieties are more suitable to be consumed in fresh form while others could be submitted to preservation treatments and consumed later (Sat et al., 2002). Therefore, it is also very important to assess the most suitable varieties to be submitted to culinary process. Recently, by studying ten red and white grapevine varieties, Lima, Bento, Baraldi, and Malheiro (2016) reported that white varieties could be more suitable for culinary process due to their higher content in phenolic compounds and higher antioxidant activity. From that study, two varieties were highlighted, Malvasia Fina which reported higher bioactive potential and higher phenolic compounds content, and Touriga Franca, with lower antioxidant potential and phenolic compounds.

Therefore, the present study intends to contribute to the knowledge related to the changes caused by pre-culinary treatments and culinary treatments in grapevine leaves. In this study, two varieties, Malvasia Fina and Touriga Franca, were selected to be submitted to blanching and boiling at three different times $(60,75$ and $90 \mathrm{~min}$ ). Three main aspects were studied: i) color changes, 
once that color is an important aspect for consumption and consumer acceptability; ii) pigments composition, namely chlorophylls and carotenoids, since they are intrinsically related to the color aspects studied in the first aspect; and iii) the volatile composition of the two varieties, since aroma is also an important aspect to consider during culinary process and for consumers' preference. To the authors' knowledge, this is the first study conducted on these varieties regarding their use for culinary use, and the first study conducted to verify the changes during culinary process.

\section{Material and methods}

\subsection{Plant material}

From a preliminary study based on the antioxidant activity and the phytochemical composition of red and white Portuguese grapevine leaf varieties (Lima et al., 2016), two varieties were selected for the present work. The two varieties selected were Malvasia Fina (MF - white variety) and Touriga Franca ( $\mathrm{TF}$ - red variety), reporting higher and lower antioxidant properties and phytochemicals content respectively (Lima et al., 2016). The two varieties were collected within the same edaphoclimatic conditions and agronomic practices. The collection was made in July 2015 and three independent samples (approximately $500 \mathrm{~g}$ of leaves) per variety were collected. Once in laboratory, leaves were visually inspected and those with signs of pests and diseases as well as mechanical damages or with birds excrements were rejected for analysis. Also, all the debris were removed and leaves were cleaned with distilled water. Dust was removed with a slightly humidified scientific paper while persistent and dried earth was removed with a jet of distilled water to avoid mechanical damages and cells disruption in the leaves.

\subsection{Culinary treatments}

In each independent sample of MF and TF grapevine leaves, five sub-samples were constituted per variety (each with 15 leaves): control samples $(\mathrm{C})$, without any culinary treatment $\left(\mathrm{MF}_{\mathrm{C}}\right.$ and $\mathrm{TF}_{\mathrm{C}}$ ); blanched leaves, submerged during $5 \mathrm{~min}$ in water at boiling temperature to simulate the domestic conditions $\left(\mathrm{MF}_{\mathrm{B}}\right.$ and $\left.\mathrm{TF}_{\mathrm{B}}\right)$; and three boiling treatments (by pressure cooking) with a duration of $60\left(\mathrm{MF}_{60}\right.$ and $\left.\mathrm{TF}_{60}\right), 75\left(\mathrm{MF}_{75}\right.$ and $\left.\mathrm{TF}_{75}\right)$ and $90 \mathrm{~min}\left(\mathrm{MF}_{90}\right.$ and $\mathrm{TF}_{90}$ ) at $120^{\circ} \mathrm{C}$. For blanched leaves and pressure cooked leaves, the ratio was $100 \mathrm{~mL}$ of water per leaf (leaves with similar size and weight). For establishing the culinary treatments to apply to grapevine leaves, a standard boiling method was applied, and after $3 \mathrm{~h}$ the leaves were still not edible (too hard, fibrous, and difficult to chew). For that reason, the option of boiling them in a pressure cooker was adopted, in order to reduce the cooking time to make leaves edible (tender and soft chewable leaves). After that, the samples were analyzed for their color, pigments concentration and volatile composition.

\subsection{Color determination}

The color of grapevine leaves was measured in both upper (adaxial) and lower (abaxial) surfaces. In each variety and treatment five leaves were selected and in each leaf four points were measured in each surface. The color was measured with a Konica Minolta model CR-400 colorimeter. Color differences $(\Delta E)$ were measured between control samples $\left(\mathrm{MF}_{\mathrm{C}}\right.$ and $\left.\mathrm{TF}_{\mathrm{C}}\right)$, considered as standard (leaves without culinary treatment) and leaves submitted to the four culinary treatments. $\Delta E$ was calculated from the monochromatic variables $L^{*}, a^{*}$, and $b^{*}$ obtained from the CIELAB method as described by Gooch (2011).

\subsection{Chlorophylls and carotenoids evaluation}

In both varieties and in the different treatments, the pigments content was studied regarding chlorophylls $a$ and $b$, total chlorophylls, and carotenoids) by using a spectrophotometric technique after the methanolic extraction as described by Ozerol and Titus (1965). The determination of pigments was carried out in three grapevine leaves in triplicate per variety and for each treatment. Briefly, $0.1 \mathrm{~g}$ of grapevine leaves were cut in small pieces and emerged in $10 \mathrm{~mL}$ of methanol during $24 \mathrm{~h}$ at $4{ }^{\circ} \mathrm{C}$ and in darkness. After that time, the absorbance of the obtained extracted was measured at 470,651, and $664 \mathrm{~nm}$. Amounts of chlorophyll $a$, chlorophyll $b$, total chlorophylls and carotenoids were calculated according to the following formulas:

$$
\begin{aligned}
& \text { Chlorophyll } a\left(\mu \mathrm{g} \mathrm{mL}^{-1}\right)=16.5 \mathrm{Abs}_{664}-8.3 \mathrm{Abs}_{651} \\
& \text { Chlorophyll } b\left(\mu \mathrm{g} \mathrm{mL}^{-1}\right)=33.8 \mathrm{Abs}_{651}-12.5 \mathrm{Abs}_{664}
\end{aligned}
$$

Total chlorophylls $\left(\mu \mathrm{g} \mathrm{mL}{ }^{-1}\right)=25.5 \mathrm{Abs}_{651}+\mathrm{Abs}_{664}$

Carotenoids $\left(\mu \mathrm{g} \mathrm{mL}^{-1}\right)=\frac{\left(1000 \mathrm{Abs}_{470}-1.62 \mathrm{Chl} a-104.69 \mathrm{Chl} b\right)}{221}$

The final values were reported as $\mathrm{mg}$ of pigment per $100 \mathrm{~g}$ of fresh leaf.

\subsection{Volatile characterization}

The characterization of volatiles from grapevine leaf varieties submitted to culinary process was performed by headspace solidphase microextraction (HS-SPME) and by gas-chromatographymass spectrometry (GC/MS).

\subsubsection{Extraction of volatile compounds by HS-SPME}

In $50 \mathrm{~mL}$ vials, $0.5 \mathrm{~g}$ of grapevine leaves were spiked with an internal standard (2-methyl-4-pentanol at $180 \mathrm{ng} \mathrm{mg}^{-1}$ of grapevine leaf in methanol) and volatiles were extracted with an SPME fiber coated with divinylbenzene/carbonex/polydimethylsiloxane (DVB/CAR/PDMS 50/30 $\mu \mathrm{m}$ ) (Supelco, Bellefonte, USA). Prior to any analysis, the DVB/CAR/PDMS fiber was conditioned in the injector port of the chromatography system at $270{ }^{\circ} \mathrm{C}$ for $1 \mathrm{~h}$, as recommended by the supplier. The entire procedure was carried out in a gas emission system (isolation) at $40^{\circ} \mathrm{C}$. The vials with the respective samples were placed $5 \mathrm{~min}$ at $40^{\circ} \mathrm{C}$ for an incisive release of the volatile compounds. After this period, the SPME fiber was exposed during $30 \mathrm{~min}$ for the compounds adsorption in the headspace. The fiber was then inserted in the injection port of the chromatography system. The HS-SPME procedure was conducted in duplicate per grapevine leaf sample with control samples (empty vials regularly).

\subsubsection{Gas-chromatography mass-spectrometry analysis (GC-MS)}

The retained compounds were eluted from the fiber by thermal adsorption for $1 \mathrm{~min}$. For cleaning and conditioning for further analyzes, the fiber was maintained during $10 \mathrm{~min}$ at $220^{\circ} \mathrm{C}$ in the injector port of the chromatography system. The gas chromatographer used was a Shimadzu GC-2010 Plus equipped with a mass spectrometer Shimadzu GC/MS-QP2010 SE detector. A TRB-5MS (30 $\mathrm{m} \times 0.25 \mathrm{~mm} \times 0.25 \mu \mathrm{m})$ column (Teknokroma, Spain) was used. The injector was set at $220^{\circ} \mathrm{C}$ and the manual injections were made in splitless mode. The mobile phase consisted of helium (Praxair, Portugal) at a linear velocity of $30 \mathrm{~cm} / \mathrm{s}$ and a total flow of $24.4 \mathrm{~mL} / \mathrm{min}$. The oven temperatures were the following: $40{ }^{\circ} \mathrm{C} / 1 \mathrm{~min} ; 2^{\circ} \mathrm{C} / \mathrm{min}$ until $220^{\circ} \mathrm{C} ; 220^{\circ} \mathrm{C}$ during $30 \mathrm{~min}$. The ionization source was maintained at $250^{\circ} \mathrm{C}$ with ionization energy of 
$70 \mathrm{eV}$, and with an ionization current of $0.1 \mathrm{kV}$. All mass spectra were acquired by electron ionization. The ionization was left off during the first $2 \mathrm{~min}$. The MS spectra fragments were compared with those obtained from a database (NIST 11), and with those of pure compounds. For quantification purposes, each sample was injected in duplicate, and the areas of the chromatographic peaks were determined by integrating the re-constructed chromatogram from the full scan chromatogram using the ion base $(\mathrm{m} / \mathrm{z}$ intensity $100 \%$ ) for each compound. For semi-quantification purposes, volatile amounts were calculated by the ratio of each individual base ion peak area to the area of the internal standard and converted to mass equivalents on the basis of the internal mass added.

\subsection{Statistical analysis}

An analysis of variance (ANOVA) was performed with SPSS software, version 22.0 (IBM Corporation, New York, U.S.A.). All dependent variables were analyzed using a one-way ANOVA with or without Welch correction depending on whether the requirement of the homogeneity of variances was fulfilled or not. The main factor studied was the effect of culinary process (blanching and boiling at different times) in the color parameters, pigments and volatiles of MF and TF grapevine leaves. Means were compared using Tukey's or Dunnett T3 test depending on whether equal variances could be assumed or not. All statistical tests were performed at a $5 \%$ significance level.

A regression analysis, using Excel from Microsoft Corporation, was established between the total chlorophylls content and the values of the monochromatic variable $a^{*}$ obtained from the color measurement of the grapevine leaves from MF and TF in the adaxial and abaxial surfaces at the culinary treatments studied.

\section{Results and discussion}

\subsection{Color of grapevine leaves under culinary process}

Grapevine leaves color was measured in the adaxial and abaxial surfaces of the two varieties studied at different culinary treatments. The results obtained are presented in Table 1 . The color of grapevine leaves changes considerably when submitted to blanching treatment or to different boiling periods (Table 1 ). Regarding $L^{*}$ (lightness), the values in both varieties during the culinary treatments in both surfaces followed similar trends. In the case of the adaxial surface, $L^{*}$ values increase from the leaves without treatment to the blanched leaves in both varieties $(40.1 \pm 1.50$ to
$44.2 \pm 1.49$ in MF, and $40.7 \pm 0.90$ to $44.4 \pm 1.51$ in TF). After that, in boiled samples, $L^{*}$ values remain stable in the MF adaxial surface, varying from $41.9 \pm 1.77$ in $\mathrm{MF}_{60}$ and $41.9 \pm 1.38 \mathrm{MF}_{90}$, to $42.4 \pm 1.43$ in $\mathrm{MF}_{75}$ (Table 1 ). In TF a gradual decrease in $L^{*}$ was registered, with $42.8 \pm 1.86,41.8 \pm 1.22$ and $40.4 \pm 1.54$ at respectively 60,75 and 90 min of boiling (Table 1). The variation from green to red is given by the monochromatic variable $a^{*}$, and in both varieties and leaves surface, the culinary treatment significantly reduced the green coloration ( $P<0.001$ for both varieties). In both surfaces for the two varieties, lower $a^{*}$ values were reported in the fresh leaves $(-14.6 \pm 1.41$ and $-12.8 \pm 1.73$ for MF in the adaxial and abaxial surfaces respectively; and $-14.1 \pm 0.88$ and $-12.9 \pm 0.44$ for TF in the adaxial and abaxial surfaces respectively). When blanched a higher increase in $a^{*}$ values was observed in the adaxial surface (Table 1 ), which means a higher loss of green coloration comparatively to the abaxial surface of both varieties. A further increase in $a^{*}$ values was reported when leaves were boiled during different periods. However, between 60 and 90 min of boiling $a^{*}$ values in both surfaces of TF didn't differ significantly. Respecting MF the losses of green color were greater than in $\mathrm{TF}$, reporting a higher increase in $a^{*}$ values. From $\mathrm{MF}_{60}$ to $\mathrm{MF}_{90} a^{*}$ values increased from $1.78 \pm 0.25$ to $2.39 \pm 0.21$ in the adaxial surface (Table 1$)$. In the abaxial surface, $a^{*}$ values increase from $\mathrm{MF}_{60}$ $(0.62 \pm 0.37)$ to $\mathrm{MF}_{75}(0.84 \pm 0.38)$ but decrease significantly $(P<0.001)$ to $\mathrm{MF}_{90}(0.36 \pm 0.14)$.

The variation from yellow to blue is given by the monochromatic variable $b^{*}$. The yellow color of grapevine leaves in both varieties and in both surfaces increases when fresh leaves are blanched (Table 1). The most significant increase was verified in the adaxial surface of MF, increasing from $21.6 \pm 3.06$ to $25.4 \pm 3.05$. In both grapevine leaves varieties, no statistical differences were observed in the adaxial surfaces between $\mathrm{MF}_{\mathrm{C}}$ and $\mathrm{MF}_{90}$ in $b^{*}$ values. At $90 \mathrm{~min}$ of boiling $b^{*}$ values were $23.6 \pm 2.16$ in $\mathrm{MF}$ and $19.8 \pm 2.34$ in TF (Table 1 ). The results obtained for the color of grapevine leaves in our study are in agreement with those reported by Sat et al. (2002). These authors studied the impact of blanching treatments on the color of grapevine leaves for canned food and observed a reduction of $a^{*}$ values and a small increase in $b^{*}$ values.

The global color changes $(\Delta E)$ of grapevine leaves in the different culinary treatments are reported in Fig. 1. Considering fresh leaves $\left(\mathrm{MF}_{\mathrm{C}}\right.$ and $\left.\mathrm{TF}_{\mathrm{C}}\right)$ as a comparison sample, the $\Delta E$ values were clearly more affected by boiling than by blanching, being this result also verified at naked eye (Fig. 1). An opposite trend was observed in the two varieties. In the MF adaxial surface, $\Delta E$ values increased with boiling time while the opposite was observed in the same

Table 1

Color parameters $\left(L^{*}, a^{*}\right.$ and $\left.b^{*}\right)$ in grapevine leaves from Malvasia Fina and Touriga Franca varieties subjected to culinary process.

\begin{tabular}{|c|c|c|c|c|c|c|}
\hline \multirow[t]{2}{*}{ Sample } & \multicolumn{3}{|c|}{ Leaves adaxial surface } & \multicolumn{3}{|c|}{ Leaves abaxial surface } \\
\hline & $L^{*}$ & $a^{*}$ & $b^{*}$ & $L^{*}$ & $a^{*}$ & $b^{*}$ \\
\hline $\mathrm{MF}_{\mathrm{C}}$ & $40.1 \pm 1.50^{\mathrm{aA}}$ & $-14.6 \pm 1.41^{\mathrm{aA}}$ & $21.6 \pm 3.06^{\mathrm{aA}}$ & $53.3 \pm 2.65^{\mathrm{cA}}$ & $-12.8 \pm 1.73^{\mathrm{aA}}$ & $25.7 \pm 3.38^{\mathrm{bA}}$ \\
\hline $\mathrm{MF}_{\mathrm{B}}$ & $44.2 \pm 1.49^{\mathrm{cA}}$ & $-5.20 \pm 1.61^{\mathrm{bA}}$ & $25.4 \pm 3.05^{\mathrm{bB}}$ & $51.1 \pm 3.13^{\mathrm{b}, \mathrm{cA}}$ & $-6.11 \pm 1.93^{\mathrm{bA}}$ & $26.1 \pm 4.62^{\mathrm{a}, \mathrm{b} f}$ \\
\hline $\mathrm{MF}_{60}$ & $41.9 \pm 1.77^{\mathrm{bA}}$ & $1.78 \pm 0.25^{\mathrm{cA}}$ & $22.2 \pm 2.57^{\mathrm{a}, \mathrm{bA}}$ & $44.8 \pm 1.43^{\mathrm{aA}}$ & $0.62 \pm 0.37^{\mathrm{c}, \mathrm{dA}}$ & $24.4 \pm 1.78^{\mathrm{bB}}$ \\
\hline $\mathrm{MF}_{75}$ & $42.4 \pm 1.43^{\mathrm{b}, \mathrm{cA}}$ & $2.16 \pm 0.23^{\mathrm{dB}}$ & $23.7 \pm 2.65^{\mathrm{a}, \mathrm{bB}}$ & $45.9 \pm 1.98^{\mathrm{a}, \mathrm{bA}}$ & $0.84 \pm 0.38^{\mathrm{dB}}$ & $24.5 \pm 2.72^{\mathrm{bB}}$ \\
\hline $\mathrm{MF}_{90}$ & $41.9 \pm 1.38^{\mathrm{bB}}$ & $2.39 \pm 0.21^{\mathrm{dB}}$ & $23.6 \pm 2.16^{\mathrm{a}, \mathrm{bB}}$ & $51.7 \pm 1.30^{\mathrm{cB}}$ & $0.36 \pm 0.14^{\mathrm{cA}}$ & $18.1 \pm 1.45^{\mathrm{aA}}$ \\
\hline$P$-Value & $<0.001^{(1)}$ & $<0.001^{(2)}$ & $0.050^{(1)}$ & $<0.001^{(2)}$ & $<0.001^{(2)}$ & $<0.001^{(2)}$ \\
\hline $\mathrm{TF}_{\mathrm{C}}$ & $40.7 \pm 0.90^{\mathrm{aA}}$ & $-14.1 \pm 0.88^{\mathrm{aA}}$ & $19.9 \pm 1.49^{\mathrm{aA}}$ & $53.2 \pm 1.05^{\mathrm{dA}}$ & $-12.9 \pm 0.44^{\mathrm{aA}}$ & $22.5 \pm 0.99^{\mathrm{bA}}$ \\
\hline $\mathrm{TF}_{\mathrm{B}}$ & $44.4 \pm 1.51^{\mathrm{cA}}$ & $-4.62 \pm 1.86^{\mathrm{bA}}$ & $21.0 \pm 1.71^{\mathrm{a}, \mathrm{bA}}$ & $48.8 \pm 2.03^{\mathrm{cA}}$ & $-5.66 \pm 1.83^{\mathrm{bA}}$ & $25.1 \pm 1.98^{\mathrm{cA}}$ \\
\hline $\mathrm{TF}_{60}$ & $42.8 \pm 1.86^{\mathrm{bA}}$ & $1.83 \pm 0.27^{\mathrm{cA}}$ & $23.0 \pm 2.72^{\mathrm{bA}}$ & $47.5 \pm 2.02^{\mathrm{b}, \mathrm{cB}}$ & $0.41 \pm 0.21^{\mathrm{cA}}$ & $21.3 \pm 2.31^{\mathrm{a}, \mathrm{b} f}$ \\
\hline $\mathrm{TF}_{75}$ & $41.8 \pm 1.22^{\mathrm{a}, \mathrm{bA}}$ & $1.87 \pm 0.31^{\mathrm{cA}}$ & $21.2 \pm 2.01^{\mathrm{a}, \mathrm{bA}}$ & $46.0 \pm 1.92^{\mathrm{a}, \mathrm{bA}}$ & $0.45 \pm 0.33^{\mathrm{cA}}$ & $21.5 \pm 2.98^{\mathrm{a}, \mathrm{b} f}$ \\
\hline $\mathrm{TF}_{90}$ & $40.4 \pm 1.54^{\mathrm{aA}}$ & $1.96 \pm 0.28^{\mathrm{cA}}$ & $19.8 \pm 2.34^{\mathrm{aA}}$ & $44.7 \pm 1.84^{\mathrm{aA}}$ & $0.61 \pm 0.24^{\mathrm{cB}}$ & $19.5 \pm 2.36^{\mathrm{aA}}$ \\
\hline$P$-Value & $<0.001^{(1)}$ & $<0.001^{(2)}$ & $0.003^{(1)}$ & $<0.001^{(2)}$ & $<0.001^{(1)}$ & $<0.001^{(2)}$ \\
\hline
\end{tabular}

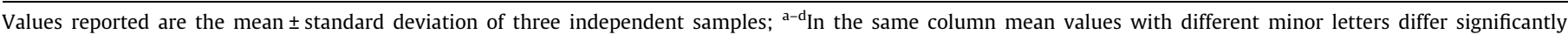

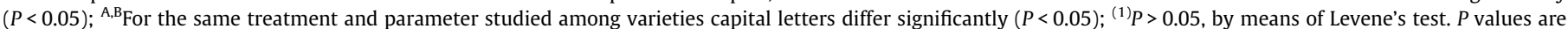

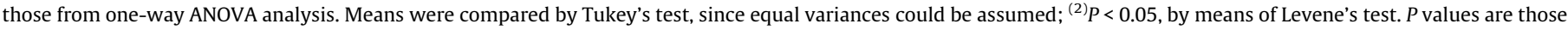
from one-way Welch ANOVA analysis. Means were compared by Dunnett T3's test, since equal variances could not be assumed. 

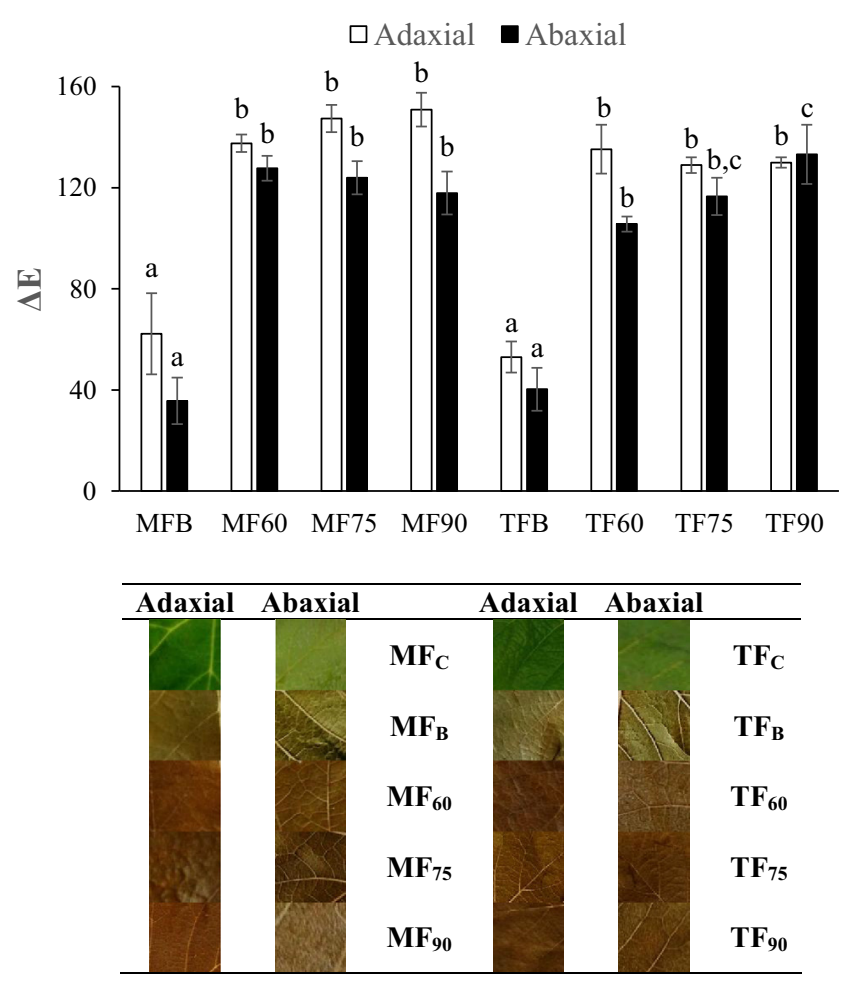

Fig. 1. Color changes $(\Delta E)$ in grapevine leaves varieties (Malvasia Fina - MF; and Touriga Franca - TF) submitted to blanching and boiling treatments $\left({ }^{\mathrm{a}-\mathrm{c}}\right.$ Values within the same variety and leaf surface with different letters differ significantly, $P<0.05$; MFC and TFC - Malvasia Fina and Touriga Franca fresh leaves; $\mathrm{MF}_{\mathrm{B}}$ and $\mathrm{TF}_{\mathrm{B}}$ - Malvasia Fina and Touriga Franca blanched leaves; $\mathrm{MF}_{60}, \mathrm{MF}_{75}, \mathrm{MF}_{90}, \mathrm{TF}_{60}, \mathrm{TF}_{75}$ and $\mathrm{TF}_{90}$ - Malvasia Fina and Touriga Franca pressure cooked leaves for 60, 75 and $90 \mathrm{~min}$ ). (For interpretation of the references to color in this figure legend, the reader is referred to the web version of this article.)

variety for the abaxial surface. Meanwhile in TF, small decreases were checked in the adaxial surface with the increase of boiling time, contrary to what happened in the abaxial surface. However, in both varieties, a great increase in $\Delta E$ was registered from blanched to boiled samples (Fig. 1), thus witnessing the nefarious effect of boiling on the pigments of grapevine leaves. The results observed in the color parameters may certainly be related to the degradation of the pigments, namely chlorophylls and carotenoids. During blanching and boiling part of the chlorophylls could be deteriorated and lead to the formation of pheophytins which could lead to the development of a yellow-brownish coloration and a decrease of green coloration (Weemaes, Ooms, Van Loey, \& Hendrickx, 1999). This hypothesis is further presented and discussed in the next section.

\subsection{Changes in the pigments content of grapevine leaves}

The pigments content of grapevine leaves from MF and TF varieties was measured in the different culinary treatments, with the results being displayed in Table 2 . In this study, the same pattern was observed in both varieties according to the culinary treatment applied. In the case of chlorophylls (a, b, and total), a small loss from fresh to blanched leaves was reported. Chlorophyll $a$ losses were around $10 \%$ and $24 \%$ in MF and TF respectively, while in chlorophyll $b$ that loss was about $29 \%$ and $45 \%$ in MF and TF respectively. Total chlorophylls losses varied between 20\% in MF and 39\% in TF when fresh and blanched leaves were compared. Higher losses were reported in the TF variety, with a higher thermal stability of chlorophyll $a$. The higher degradation rate of chlorophyll $b$ was also a subject of study to Rudra, Sarkar, and Shivhare (2008) in blanched coriander leaves. The carotenoids content showed a contrary tendency to that presented by chlorophylls, as their content increased in blanched leaves. The increase was similar in both varieties, with an increase of about $25 \%$ in their carotenoids con-

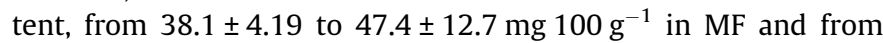
$38.8 \pm 6.74$ to $48.6 \pm 2.89 \mathrm{mg} 100 \mathrm{~g}^{-1}$ in TF (Table 2). In other vegetables, carotenoids content also increases with pre-heating treatments (Sánchez, Baranda, \& Marañón, 2014). This increase could be related to the application of temperature during the blanching step, which causes the denaturation of leaves proteins, helping thereafter in the release of carotenoids, thus increasing their bioavailability (Maiani et al., 2009) since carotenes are incorporated in protein complexes inside the chloroplasts (Bernhardt \& Schlich, 2006).

When leaves were submitted to boiling processes, the degradation rate increased significantly comparatively to fresh and blanched samples. At 60 min of boiling, the losses of chlorophylls were about $68 \%$ in MF, increasing to 70 and $76 \%$ at 75 and 90 min of heating respectively. In TF, the losses were even higher with 75,76 and $81 \%$ of chlorophylls losses at 60,75 and $90 \mathrm{~min}$ of boiling. Regarding carotenoids, after the initial increase during the blanching step, their content decreased considerably with the boiling time. Nevertheless carotenoids were far more stable than chlorophylls, since comparatively to fresh leaves, $\mathrm{MF}_{90}$ lost $14 \%$ of the total carotenoids (32.6 $\pm 4.64 \mathrm{mg} 100 \mathrm{~g}^{-1}$ at $\mathrm{MF}_{90}$; Table 2) while $\mathrm{TF}_{90}$ lost $21 \%\left(30.6 \pm 5.73 \mathrm{mg} 100 \mathrm{~g}^{-1}\right.$ at $\mathrm{TF}_{90}$; Table 2). In fact, in MF, due to the increase of carotenoids during the blanching step, the carotenoids content was even higher in $\mathrm{MF}_{60}$ and $\mathrm{MF}_{75}$ than that reported in $\mathrm{MF}_{\mathrm{C}}$ (Table 2). Pigments loss was lower in MF comparatively to TF. Such observation could be related to the fact that MF present a higher content in antioxidant molecules, like phenolic compounds and flavonoids (around 120\%) (Fernandes et al., 2013; Lima et al., 2016), which may protect the leaves against thermal treatment.

The loss of pigments, namely chlorophylls, was related to the loss of leaves green coloration reported in Table 1 and Fig. 1. When the data from total chlorophylls was correlated with the data of the monochromatic variable $a^{*}$, strong negative correlations were established for both varieties and in both surfaces (Table 3 ). Therefore, the increase of $a^{*}$ values in grapevine leaves is ascribed to lower total chlorophylls due to the degradation kinetics of this pigment, causing the reduction of green coloration (Steet \& Tong, 1996).

\subsection{Volatile composition of grapevine leaves under culinary process}

From the volatile profile of MF and TF grapevine leaves submitted to culinary treatment, 37 volatiles were identified and quantified, belonging to different chemical classes (Table 4). Eight aldehydes, four alcohols, one ketone, three norisoprenoids derivatives, eight esters, six sesquiterpenes, five terpenes, and two other compounds are present in the volatile profile of the grapevine leaves and are presented in Table 4. Significant quantitative and qualitative changes were reported in the volatile profile of grapevine leaves of both varieties according to the culinary treatment, as it can be inferred in Fig. 2 and Table 4. In both varieties, the main volatiles present in fresh leaves are the GLV's (Green Leaf Volatiles), like the ester ( $Z$ )-3-hexenyl acetate $(8672 \pm 2184$ and $10,353 \pm 1429 \mu \mathrm{g} 100 \mathrm{~g}^{-1}$ for MF and TF respectively), the alcohol (Z)-3-hexen-1-ol (3383 \pm 961 and $4514 \pm 981 \mu \mathrm{g} 100 \mathrm{~g}^{-1}$ for $\mathrm{MF}$ and TF respectively) and the aldehyde ( $Z$ )-3-hexenal (1528 \pm 608 and $922 \pm 281 \mu \mathrm{g} 100 \mathrm{~g}^{-1}$ for MF and TF respectively) (Table 4). These volatiles are formed from the lipoxygenase pathway (LOX) (Hassan, Zainal, \& Ismail, 2015), through the oxidation of linoleic acid, and by the action of endogenous enzymes like lipoxygenase, hydroperoxide lyase, alcohol dehydrogenase, and alcohol acetyl 
Table 2

Chlorophylls and carotenoids content (mg 100 g leaves $^{-1}$ ) of grapevine leaves from Malvasia Fina and Touriga Franca varieties submitted to culinary process.

\begin{tabular}{|c|c|c|c|c|}
\hline Sample & Chlorophyll $a$ & Chlorophyll $b$ & Total chlorophyll & Carotenoids \\
\hline $\mathrm{MF}_{\mathrm{C}}$ & $23.5 \pm 1.73^{\mathrm{cA}}$ & $29.3 \pm 2.43^{\mathrm{dA}}$ & $52.8 \pm 4.16^{\mathrm{cA}}$ & $38.1 \pm 4.19^{\mathrm{a}, \mathrm{b} f}$ \\
\hline $\mathrm{MF}_{\mathrm{B}}$ & $21.1 \pm 6.69^{\mathrm{cA}}$ & $20.8 \pm 5.74^{\mathrm{cA}}$ & $42.0 \pm 12.3^{\mathrm{cA}}$ & $47.4 \pm 12.7^{\mathrm{a}, \mathrm{b} f}$ \\
\hline $\mathrm{MF}_{60}$ & $8.80 \pm 0.57^{\mathrm{bB}}$ & $8.31 \pm 0.63^{\mathrm{bA}}$ & $17.1 \pm 1.06^{\mathrm{bA}}$ & $42.9 \pm 2.87^{\mathrm{bB}}$ \\
\hline $\mathrm{MF}_{75}$ & $8.06 \pm 1.25^{\mathrm{a}, \mathrm{bA}}$ & $7.61 \pm 1.61^{\mathrm{a}, \mathrm{bA}}$ & $15.7 \pm 2.86^{\mathrm{a}, \mathrm{bA}}$ & $40.5 \pm 2.71^{\mathrm{bA}}$ \\
\hline $\mathrm{MF}_{90}$ & $6.55 \pm 0.70^{\mathrm{aA}}$ & $5.77 \pm 0.70^{\mathrm{aA}}$ & $12.4 \pm 1.39^{\mathrm{aA}}$ & $32.6 \pm 4.64^{\mathrm{aA}}$ \\
\hline$P$-Value & $<0.001^{* *}$ & $<0.001^{* *}$ & $<0.001^{* *}$ & $0.003^{* *}$ \\
\hline $\mathrm{TFC}$ & $25.9 \pm 5.82^{\mathrm{bA}}$ & $35.2 \pm 8.40^{\mathrm{dA}}$ & $63.7 \pm 12.0^{\mathrm{cB}}$ & $38.8 \pm 6.74^{\mathrm{aA}}$ \\
\hline $\mathrm{TF}_{\mathrm{B}}$ & $19.6 \pm 4.05^{\mathrm{bA}}$ & $19.4 \pm 4.90^{\mathrm{cA}}$ & $38.8 \pm 9.19^{\mathrm{bA}}$ & $48.6 \pm 2.89^{\mathrm{bA}}$ \\
\hline $\mathrm{TF}_{60}$ & $7.75 \pm 0.89^{\mathrm{aA}}$ & $7.93 \pm 1.23^{\mathrm{bA}}$ & $15.7 \pm 2.13^{\mathrm{aA}}$ & $33.9 \pm 3.86^{\mathrm{aA}}$ \\
\hline $\mathrm{TF}_{75}$ & $7.95 \pm 1.91^{\mathrm{aA}}$ & $6.99 \pm 1.78^{\mathrm{a}, \mathrm{bA}}$ & $15.0 \pm 3.66^{\mathrm{aA}}$ & $35.3 \pm 9.43^{\mathrm{aA}}$ \\
\hline $\mathrm{TF}_{90}$ & $6.16 \pm 1.46^{\mathrm{aA}}$ & $5.68 \pm 1.24^{\mathrm{aA}}$ & $11.9 \pm 2.71^{\mathrm{aA}}$ & $30.6 \pm 5.73^{\mathrm{aA}}$ \\
\hline$P$-Value & $<0.001^{* *}$ & $<0.001^{* *}$ & $<0.001^{* *}$ & $<0.001^{* *}$ \\
\hline
\end{tabular}

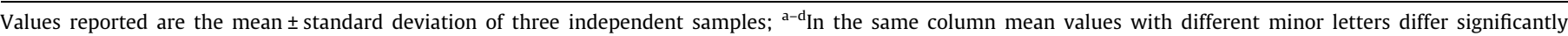

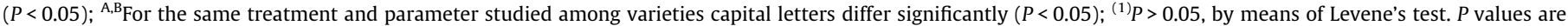

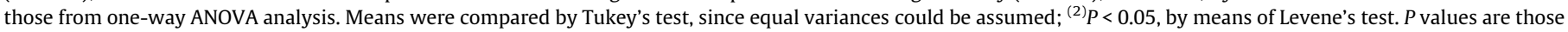
from one-way Welch ANOVA analysis. Means were compared by Dunnett T3's test, since equal variances could not be assumed.

Table 3

Correlation between total chlorophylls content and monochromatic variable $a^{*}$ of Malvasia Fina and Touriga Franca varieties submitted to culinary process.

\begin{tabular}{|c|c|c|c|c|c|c|}
\hline \multirow[t]{2}{*}{ Variety } & \multicolumn{3}{|l|}{ Adaxial surface } & \multicolumn{3}{|l|}{ Abaxial surface } \\
\hline & Equation & $\mathrm{R}^{2}$ & $P^{\mathrm{a}}$ & Equation & $\mathrm{R}^{2}$ & $\overline{P^{\mathrm{a}}}$ \\
\hline MF & $y=-0.024 x+0.221$ & 0.803 & $* * *$ & $y=-0.029 x+0.186$ & 0.804 & $* * *$ \\
\hline $\mathrm{TF}$ & $y=-0.033 x+0.203$ & 0.895 & $* * *$ & $y=-0.039 x+0.156$ & 0.903 & $* * *$ \\
\hline
\end{tabular}

a n.s. not significant; ${ }^{*} P \leqslant 0.05$ - significant correlation; ${ }^{* *} P \leqslant 0.01$ - very significant correlation; ${ }^{* * *} P \leqslant 0.001-$ extremely significant correlation.

transferase, therefore producing aldehydes $((Z)$-3-hexenal), alcohols ((Z)-3-hexen-1-ol), and esters ((Z)-3-hexenyl acetate). In $\mathrm{MF}_{\mathrm{C}}$, these three volatiles are responsible for $82 \%$ of the total volatiles amount, and for $86 \%$ in $\mathrm{TF}_{\mathrm{C}}$. These volatiles are important since they are responsible for the green, cut-grass and citrus sensations (Iyer, Sacks, \& Padilla-Zakour, 2010) in the grapevine leaves. When leaves were blanched, (Z)-3-hexenal and (Z)-3-hexen-1-ol disappeared from the volatile profiles of both varieties (Fig. 2 and Table 4). Besides a short blanching period, the main GLV's were lost, mainly due to the thermal treatment. Only $(Z)$-3-hexenyl acetate remained after blanching but with a drastic significant reduction in both varieties (Table 4). In MF, the reduction was from $8672 \pm 2184$ to $202 \pm 19 \mu \mathrm{g} 100 \mathrm{~g}^{-1}$ (97.7\% of the content lost) and in TF, the reduction was from $10,353 \pm 1429$ to $627 \pm 257 \mu \mathrm{g}$ $100 \mathrm{~g}^{-1}$ (93.9\% of the content lost). Such reduction is related to the thermal treatment which led to the inactivation of the mentioned enzymes that intervene in the LOX pathway, causing the enzymes denaturation (Luaces, Sanz, \& Pérez, 2007). A sesquiterpene, caryophyllene (compound n. 27 in Fig. 2 and Table 4), present in considerable amounts in $\mathrm{MF}_{\mathrm{C}}$ and $\mathrm{TF}_{\mathrm{C}}$ (390 \pm 74 and $548 \pm 332 \mu \mathrm{g} 100 \mathrm{~g}^{-1}$ respectively), reported contrary trends when leaves were blanched, decreasing significantly in MF (to $10 \pm 4 \mu \mathrm{g}$ $100 \mathrm{~g}^{-1}$ ) and increasing to $719 \pm 309 \mu \mathrm{g} 100 \mathrm{~g}^{-1}$ in TF (Table 4). This compound is responsible for the woody sensation (MayuoniKirshinbaum \& Porat, 2014), an aroma scented mainly in TF and in the boiled samples as well. Other volatiles, mainly esters present in fresh leaves, were reduced drastically when leaves were blanched or simply disappeared from the volatile profile, like methyl (Z)-3-hexanoate, ( $Z$ )-3-hexenyl butanoate, and (Z)-3hexenyl isovalerate (Table 4 ). In a trend contrary to these compounds and to the trend presented by GLV's, several volatiles appeared in the profile of blanched grapevine leaves, like the terpenes $\beta$-cymene, limonene and linalool mainly in MF and in low amounts (Table 4). However, the appearance of pentanal can be inferred in Fig. 2 (compound $\mathrm{n}^{\circ} 1$ in Fig. 2 and Table 4) when leaves were blanched, being absent from fresh leaves. The formation of this aldehyde is apparently enhanced by the blanching step, reporting considerable amounts in MF (502 $\pm 161 \mu \mathrm{g} 100 \mathrm{~g}^{-1}$ ) and in TF $\left(630 \pm 163 \mu \mathrm{g} 100 \mathrm{~g}^{-1}\right)$. Pentanal contents are greatly increased during the blanching step of other vegetables like leek (Nielsen, Larsen, \& Poll, 2004), broccoli (Hansen, Laustsen, Olsen, Poll, \& Sorensen, 1997), and spinach (Kebede et al., 2013). Therefore, due to the application of temperature, the blanching step induces the formation of pentanal in vegetables.

The ketone 6-methyl-5-hepten-2-one (compound $n^{\circ} 13$ in Fig. 2 and Table 4) was another volatile that considerably increased when grapevine leaves were blanched. Present in low amounts in fresh leaves ( $20 \pm 6$ and $15 \pm 3 \mu \mathrm{g} 100 \mathrm{~g}^{-1}$ respectively in MF and $\mathrm{TF})$, this ketone reported $1499 \pm 569$ and $1173 \pm 409 \mu \mathrm{g} 100 \mathrm{~g}^{-1}$ in blanched MF and TF grapevine leaves respectively, thus being the most abundant volatile (Table 4). This ketone is formed when fruits and vegetables are submitted to high temperature like blanching (Whitaker \& Saftner, 2000). The formation of 6methyl-5-hepten-2-one is derived from the oxidative cleavage of lycopene (Goff \& Klee, 2006; Kanasawud \& Crouzet, 1990) present in grapevine leaves (Dinis et al., 2016). Therefore, the formation of this ketone could be ascribed to oxidative reactions undertaken during blanching. In spice paprika, the application of heating $\left(90^{\circ} \mathrm{C} / 60 \mathrm{~min}\right)$ nearly triplicates the amounts of 6-methyl-5hepten-2-one (Cremer \& Eichner, 2000).

When leaves were boiled at 60, 75 and 90 min the main compounds present in both varieties continued to be pentanal and 6methyl-5-hepten-2-one, and caryophyllene mainly in TF (Table 4). The GLV (Z)-3-hexenyl acetate reduced its content from fresh to blanched leaves about $97.7 \%$ in MF and $93.9 \%$ in TF. Once leaves were boiled, this ester was completely deteriorated and was absent from the volatile profile of both varieties at 60, 75 and $90 \mathrm{~min}$ (Table 4). During boiling in both varieties, there were no differences for pentanal amounts during blanching and boiling, even during $90 \mathrm{~min}(P=0.106$ in $\mathrm{MF}$ and $P=0.096$ in TF). Nevertheless, a continuous decrease is reported, since pentanal content in the

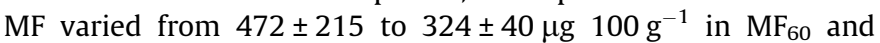
$\mathrm{MF}_{90}$, while in TF it varied from $493 \pm 125$ to $464 \pm 53 \mu \mathrm{g} 100 \mathrm{~g}^{-1}$ in $\mathrm{TF}_{60}$ and $\mathrm{TF}_{90}$ respectively (Table 4). With regard to 6-methyl- 
Table 4

Volatile profile of grapevine leaves ( $\mu \mathrm{g} 100 \mathrm{~g}^{-1}$ of fresh grapevine leaves expressed on a IS equivalent basis) from Malvasia Fina and Touriga Franca varieties submitted to culinary process.

\begin{tabular}{|c|c|c|c|c|c|c|c|c|c|c|c|c|c|}
\hline $\mathrm{N}^{\circ}$ & Compound & $\mathrm{MF}_{\mathrm{C}}$ & $\mathrm{MF}_{\mathrm{B}}$ & $\mathrm{MF}_{60}$ & $\mathrm{MF}_{75}$ & $\mathrm{MF}_{90}$ & $P$-Value & $\mathrm{TF}_{\mathrm{C}}$ & $\mathrm{TF}_{\mathrm{B}}$ & $\mathrm{TF}_{60}$ & $\mathrm{TF}_{75}$ & $\mathrm{TF}_{90}$ & $P$-value \\
\hline \multicolumn{14}{|c|}{ Aldehydes } \\
\hline 1 & Pentanal & n.d. & $502 \pm 161^{\mathrm{aA}}$ & $472 \pm 215^{\mathrm{aA}}$ & $350 \pm 80^{\mathrm{aA}}$ & $324 \pm 40^{\mathrm{aA}}$ & $0.106^{*}$ & n.d. & $630 \pm 163^{\mathrm{aA}}$ & $493 \pm 125^{\mathrm{aA}}$ & $516 \pm 87^{\mathrm{aB}}$ & $464 \pm 53^{\mathrm{aB}}$ & $0.096^{*}$ \\
\hline 2 & (Z)-3-hexenal & $1528 \pm 608^{A}$ & n.d. & n.d. & n.d. & n.d. & - & $922 \pm 281^{A}$ & n.d. & n.d. & n.d. & n.d. & - \\
\hline 3 & (E)-2-hexenal & $166 \pm 78^{A}$ & n.d. & n.d. & n.d. & n.d. & - & $160 \pm 70^{A}$ & n.d. & n.d. & n.d. & n.d. & - \\
\hline 4 & Heptanal & $54 \pm 12^{\mathrm{c}}$ & $41 \pm 18^{\mathrm{b}, \mathrm{cA}}$ & $25 \pm 7^{\mathrm{a}, \mathrm{bA}}$ & n.d. & $22 \pm 2^{\mathrm{a}}$ & $<0.001^{*}$ & n.d. & $93 \pm 57^{\mathrm{aA}}$ & $27 \pm 3^{\mathrm{aA}}$ & $31 \pm 10^{\mathrm{a}}$ & $36 \pm 8^{a}$ & $0.040^{* *}$ \\
\hline 5 & $(E, E)$-2,4-hexadienal & $86 \pm 11^{\mathrm{A}}$ & n.d. & n.d. & n.d. & n.d. & - & $77 \pm 15^{\mathrm{A}}$ & n.d. & n.d. & & n.d. & - \\
\hline 6 & Octanal & $62 \pm 20^{\mathrm{aA}}$ & $128 \pm 26^{\mathrm{bA}}$ & $83 \pm 17^{\mathrm{aA}}$ & $74 \pm 14^{\mathrm{aA}}$ & $67 \pm 6^{\mathrm{aA}}$ & $<0.001^{*}$ & $85 \pm 17^{\mathrm{aA}}$ & $170 \pm 61^{\mathrm{aA}}$ & $81 \pm 10^{\mathrm{aA}}$ & $89 \pm 13^{\mathrm{aA}}$ & $77 \pm 18^{\mathrm{aA}}$ & $0.056^{* *}$ \\
\hline 7 & Nonanal & $41 \pm 7^{\mathrm{aA}}$ & $196 \pm 23^{\mathrm{cA}}$ & $161 \pm 51^{\mathrm{b}, \mathrm{cA}}$ & $108 \pm 22^{\mathrm{bA}}$ & $107 \pm 21^{\mathrm{bA}}$ & $<0.001^{* *}$ & $49 \pm 16^{\mathrm{aA}}$ & $201 \pm 45^{\mathrm{cA}}$ & $134 \pm 3^{\mathrm{b}, \mathrm{cA}}$ & $143 \pm 23^{\mathrm{b}, \mathrm{cB}}$ & $107 \pm 29^{\mathrm{bA}}$ & $<0.001^{* *}$ \\
\hline \multirow[t]{2}{*}{8} & Decanal & $17 \pm 4^{\mathrm{aA}}$ & $42 \pm 11^{\mathrm{bA}}$ & $32 \pm 10^{\mathrm{a}, \mathrm{bA}}$ & $31 \pm 12^{\mathrm{a}, \mathrm{bA}}$ & $31 \pm 5^{\mathrm{a}, \mathrm{bA}}$ & $0.002^{*}$ & $16 \pm 2^{\mathrm{aA}}$ & $41 \pm 16^{\mathrm{b}, \mathrm{cA}}$ & $36 \pm 7^{\mathrm{b}, \mathrm{cA}}$ & $55 \pm 16^{\mathrm{cB}}$ & $33 \pm 10^{\mathrm{a}, \mathrm{bA}}$ & $<0.001^{*}$ \\
\hline & $\Sigma$ aldehydes & $1954 \pm 669^{\mathrm{CA}}$ & $908 \pm 136^{\mathrm{b}, \mathrm{cA}}$ & $772 \pm 233^{\mathrm{a}}$ & $563 \pm 100^{\mathrm{aA}}$ & $551 \pm 58^{\mathrm{aA}}$ & $<0.001^{* *}$ & $1308 \pm 373^{\mathrm{aA}}$ & $1135 \pm 278^{\mathrm{aA}}$ & $771 \pm 127^{\mathrm{aA}}$ & $835 \pm 89^{\mathrm{aB}}$ & $716 \pm 113^{\mathrm{aB}}$ & $0.012^{* *}$ \\
\hline \multicolumn{14}{|c|}{ Alcohols } \\
\hline 9 & (Z)-3-hexen-1-ol & $3383 \pm 961^{A}$ & n.d. & n.d. & n.d. & n.d. & - & $4514 \pm 981^{\mathrm{A}}$ & n.d. & n.d. & n.d. & n.d. & - \\
\hline 10 & Benzyl alcohol & $57 \pm 12^{\mathrm{A}}$ & n.d. & n.d. & n.d. & n.d. & - & $73 \pm 21^{\mathrm{A}}$ & n.d. & n.d. & n.d. & n.d. & - \\
\hline 11 & 1-Octanol & n.d. & $16 \pm 3^{\mathrm{A}}$ & n.d. & n.d. & n.d. & - & n.d. & $22 \pm 1^{\mathrm{BB}}$ & n.d. & $16 \pm 4^{\mathrm{a}}$ & n.d. & $0.018^{*}$ \\
\hline \multirow[t]{2}{*}{12} & Phenylethyl alcohol & $35 \pm 18^{\mathrm{A}}$ & n.d. & n.d. & n.d. & n.d. & - & $22 \pm 9^{A}$ & n.d. & n.d. & n.d. & n.d. & \\
\hline & $\Sigma$ alcohols & $3475 \pm 983^{\mathrm{bA}}$ & $16 \pm 3^{\mathrm{aA}}$ & n.d. & n.d. & n.d. & $<0.001^{* *}$ & $4609 \pm 1004^{\mathrm{bA}}$ & $22 \pm 3^{\mathrm{aB}}$ & n.d. & $16 \pm 4^{\mathrm{a}}$ & n.d. & $<0.001^{* *}$ \\
\hline \multicolumn{14}{|c|}{ Ketones } \\
\hline \multirow[t]{2}{*}{13} & 6-Methyl-5-hepten-2-one & $20 \pm 6^{\mathrm{aA}}$ & $1499 \pm 569^{\mathrm{cA}}$ & $358 \pm 177^{\mathrm{bA}}$ & $\underset{b A}{318 \pm 182^{\mathrm{a}}}$ & $265 \pm 108^{\mathrm{bA}}$ & $<0.001^{* *}$ & $15 \pm 3^{\mathrm{aA}}$ & $1173 \pm 409^{\mathrm{bA}}$ & $559 \pm 90^{\mathrm{bB}}$ & $689 \pm 180^{\mathrm{bB}}$ & $548 \pm 242^{\mathrm{bB}}$ & $<0.001^{* *}$ \\
\hline & $\Sigma$ cetonas & $20 \pm 6^{\mathrm{aA}}$ & $1499 \pm 569^{\mathrm{cA}}$ & $358 \pm 177^{\mathrm{bA}}$ & $\begin{array}{l}318 \pm 182^{\mathrm{a}} \\
\mathrm{bA}\end{array}$ & $265 \pm 108^{\mathrm{bA}}$ & $<0.001^{* *}$ & $15 \pm 3^{\mathrm{aA}}$ & $1173 \pm 409^{\mathrm{bA}}$ & $559 \pm 90^{\mathrm{bB}}$ & $689 \pm 180^{\mathrm{bB}}$ & $548 \pm 242^{\mathrm{bB}}$ & $<0.001^{* *}$ \\
\hline \multicolumn{14}{|c|}{ Norisoprenoids derivatives } \\
\hline 14 & $\beta$-Cytral & n.d. & n.d. & n.d. & n.d. & n.d. & - & n.d. & $67 \pm 28^{\mathrm{a}}$ & $74 \pm 20^{\mathrm{a}}$ & $97 \pm 32^{\mathrm{a}}$ & $104 \pm 46^{\mathrm{a}}$ & $0.183^{*}$ \\
\hline 15 & $\beta$-Cyclocitral & n.d. & $9 \pm 1^{\mathrm{A}}$ & n.d. & n.d. & n.d. & - & n.d. & $10 \pm 2^{\mathrm{A}}$ & n.d. & n.d. & n.d. & - \\
\hline \multirow[t]{2}{*}{16} & (Z)-Geranylacetone & n.d. & n.d. & $11 \pm 6^{\mathrm{aA}}$ & $7 \pm 1^{\mathrm{aA}}$ & $9 \pm 3^{\mathrm{aA}}$ & $0.439^{*}$ & n.d. & $25 \pm 12^{\mathrm{a}, \mathrm{b}}$ & $17 \pm 5^{\mathrm{a}, \mathrm{bA}}$ & $21 \pm 3^{\mathrm{bB}}$ & $14 \pm 3^{\mathrm{aB}}$ & $0.014^{* *}$ \\
\hline & $\Sigma$ norisoprenoids derivatives & n.d. & $9 \pm 1^{\mathrm{aA}}$ & $11 \pm 6^{\mathrm{aA}}$ & $7 \pm 1^{\mathrm{aA}}$ & $9 \pm 3^{\mathrm{aA}}$ & $0.539^{*}$ & n.d. & $102 \pm 41^{\mathrm{aB}}$ & $90 \pm 18^{\mathrm{aB}}$ & $118 \pm 34^{\mathrm{aB}}$ & $118 \pm 48^{\mathrm{aB}}$ & $0.501^{*}$ \\
\hline \multicolumn{14}{|c|}{ Esters } \\
\hline 17 & Methyl hexanoate & n.d. & n.d. & $17 \pm 4^{\mathrm{aA}}$ & $14 \pm 3^{\mathrm{aA}}$ & n.d. & $0.120^{*}$ & $27 \pm 6^{\mathrm{b}}$ & $13 \pm 1^{\mathrm{a}}$ & $15 \pm 3^{\mathrm{aA}}$ & $12 \pm 3^{\mathrm{aA}}$ & $13 \pm 3^{a}$ & $<0.001^{*}$ \\
\hline 18 & Methyl (Z)-3-hexenoate & $647 \pm 376^{\mathrm{A}}$ & n.d. & n.d. & n.d. & n.d. & - & $612 \pm 237^{A}$ & n.d. & n.d. & n.d. & n.d. & - \\
\hline 19 & (Z)-3-hexenyl acetate & $8672 \pm 2184^{\mathrm{bA}}$ & $202 \pm 19^{\mathrm{aA}}$ & n.d. & n.d. & n.d. & $<0.001^{*}$ & $10,353 \pm 1429^{\mathrm{bA}}$ & $627 \pm 257^{\mathrm{aB}}$ & n.d. & n.d. & n.d. & $<0.001^{*}$ \\
\hline 20 & Hexyl acetate & $57 \pm 21^{\mathrm{aA}}$ & $84 \pm 45^{\mathrm{aA}}$ & $61 \pm 15^{\mathrm{aA}}$ & $53 \pm 14^{\mathrm{aA}}$ & $51 \pm 11^{\mathrm{aA}}$ & $0.475^{* *}$ & $61 \pm 8^{\mathrm{aA}}$ & $51 \pm 10^{\mathrm{aA}}$ & $61 \pm 9^{\mathrm{aA}}$ & $55 \pm 8^{\mathrm{aA}}$ & $53 \pm 10^{\mathrm{aA}}$ & $0.207^{*}$ \\
\hline 21 & (Z)-3-hexenyl butanoate & $878 \pm 584^{\mathrm{bA}}$ & $66 \pm 27^{\mathrm{aA}}$ & n.d. & n.d. & n.d. & $0.019^{*}$ & $368 \pm 113^{\mathrm{bA}}$ & $73 \pm 26^{\mathrm{aA}}$ & n.d. & n.d. & n.d. & $0.001^{* *}$ \\
\hline 22 & Hexyl butanoate & $13 \pm 3^{\mathrm{aA}}$ & $27 \pm 11^{\mathrm{aA}}$ & $15 \pm 1^{\mathrm{aA}}$ & $15 \pm 5^{\mathrm{aA}}$ & $17 \pm 2^{\mathrm{aA}}$ & $0.020^{* *}$ & $28 \pm 14^{\mathrm{bB}}$ & $16 \pm 3^{\mathrm{aA}}$ & $19 \pm 2^{\mathrm{a}, \mathrm{bB}}$ & $21 \pm 3^{\mathrm{a}, \mathrm{bB}}$ & $20 \pm 2^{\mathrm{a}, \mathrm{bB}}$ & $0.035^{*}$ \\
\hline 23 & (Z)-3-hexenyl isovalerate & $150 \pm 93^{\mathrm{bA}}$ & $47 \pm 30^{\mathrm{aA}}$ & n.d. & n.d. & n.d. & $0.041^{*}$ & $94 \pm 49^{\mathrm{bA}}$ & $28 \pm 15^{\mathrm{aA}}$ & n.d. & n.d. & n.d. & $0.011^{*}$ \\
\hline \multirow[t]{2}{*}{24} & Hexyl 2-methylbutanoate & n.d. & $25 \pm 10^{\mathrm{bA}}$ & $13 \pm 1^{\mathrm{aA}}$ & $16 \pm 4^{\mathrm{a}, \mathrm{bA}}$ & $19 \pm 2^{\mathrm{a}, \mathrm{bA}}$ & $0.008^{*}$ & $16 \pm 3^{\mathrm{a}}$ & $16 \pm 4^{\mathrm{aA}}$ & $19 \pm 4^{\mathrm{aA}}$ & $19 \pm 5^{\mathrm{aA}}$ & $22 \pm 4^{\mathrm{aA}}$ & $0.137^{*}$ \\
\hline & $\Sigma$ esters & $10,416 \pm 2995^{\mathrm{cA}}$ & $450 \pm 73^{\mathrm{bA}}$ & $105 \pm 21^{\mathrm{aA}}$ & $98 \pm 24^{\mathrm{aA}}$ & $87 \pm 12^{\mathrm{aA}}$ & $<0.001^{* *}$ & $11,561 \pm 1700^{\mathrm{cA}}$ & $824 \pm 261^{\mathrm{bB}}$ & $113 \pm 16^{\mathrm{aA}}$ & $107 \pm 15^{\mathrm{aA}}$ & $108 \pm 12^{\mathrm{aB}}$ & $<0.001^{* *}$ \\
\hline \multicolumn{14}{|c|}{ Sesquiterpenes } \\
\hline 25 & $\alpha$-Ilangene & n.d. & n.d. & n.d. & $10 \pm 3$ & n.d. & - & n.d. & n.d. & n.d. & n.d. & $7 \pm 1$ & - \\
\hline 26 & Copaene & n.d. & n.d. & n.d. & $6 \pm 2$ & n.d. & - & n.d. & n.d. & n.d. & n.d. & n.d. & - \\
\hline 27 & Caryophyllene & $390 \pm 74^{\mathrm{bA}}$ & $10 \pm 4^{\mathrm{aA}}$ & $12 \pm 9^{\mathrm{aA}}$ & $13 \pm 4^{\mathrm{aA}}$ & $356 \pm 130^{\mathrm{bA}}$ & $<0.001^{* *}$ & $548 \pm 332^{\mathrm{aA}}$ & $719 \pm 309^{\mathrm{aB}}$ & $544 \pm 198^{\mathrm{aB}}$ & $489 \pm 189^{\mathrm{aB}}$ & $397 \pm 71^{\mathrm{aA}}$ & $0.248^{*}$ \\
\hline 28 & $\begin{array}{l}\text { Sesquiterpene-like } \\
\text { compound } 1\end{array}$ & n.d. & n.d. & n.d. & n.d. & n.d. & - & $21 \pm 5^{\mathrm{a}, \mathrm{b}}$ & $24 \pm 10^{\mathrm{b}}$ & $17 \pm 6^{\mathrm{a}, \mathrm{b}}$ & $14 \pm 4^{\mathrm{a}, \mathrm{b}}$ & $13 \pm 4^{\mathrm{a}}$ & $0.018^{*}$ \\
\hline 29 & $\alpha$-Caryophyllene & n.d. & n.d. & n.d. & n.d. & $18 \pm 6^{\mathrm{A}}$ & - & $25 \pm 16^{\mathrm{a}}$ & $31 \pm 14^{\mathrm{a}}$ & $26 \pm 10^{\mathrm{a}}$ & $24 \pm 10^{\mathrm{a}}$ & $22 \pm 8^{\mathrm{a}, \mathrm{A}}$ & $0.701^{*}$ \\
\hline \multirow[t]{2}{*}{30} & $\alpha$-Farnesene & n.d. & n.d. & n.d. & $4 \pm 1^{\mathrm{a}}$ & $5 \pm 2^{\mathrm{a}}$ & $0.188^{*}$ & $4 \pm 1$ & & & & & - \\
\hline & $\Sigma$ sesquiterpenes & $390 \pm 74^{\mathrm{cA}}$ & $10 \pm 4^{\mathrm{aA}}$ & $12 \pm 9^{\mathrm{aA}}$ & $32 \pm 7^{\mathrm{bA}}$ & $378 \pm 138^{\mathrm{cA}}$ & $<0.001^{* *}$ & $599 \pm 352^{\mathrm{aA}}$ & $775 \pm 332^{\mathrm{aB}}$ & $587 \pm 214^{\mathrm{aB}}$ & $527 \pm 203^{\mathrm{aB}}$ & $440 \pm 77^{\mathrm{aA}}$ & $0.264^{*}$ \\
\hline \multicolumn{14}{|c|}{ Terpenes } \\
\hline 31 & psi-Cumene & $86 \pm 13^{\mathrm{cB}}$ & $57 \pm 6^{\mathrm{bA}}$ & $46 \pm 3^{\mathrm{a}, \mathrm{bA}}$ & $44 \pm 5^{\mathrm{aA}}$ & $44 \pm 3^{\mathrm{aA}}$ & $<0.001^{*}$ & $70 \pm 10^{\mathrm{cA}}$ & $63 \pm 13^{\mathrm{b}, \mathrm{cA}}$ & $53 \pm 10^{\mathrm{a}, \mathrm{bA}}$ & $51 \pm 5^{\mathrm{a}, \mathrm{bA}}$ & $47 \pm 4^{\mathrm{aA}}$ & $0.001^{*}$ \\
\hline 32 & $\beta$-Cymene & n.d. & $30 \pm 14^{\mathrm{bB}}$ & $26 \pm 8^{\mathrm{a}, \mathrm{bA}}$ & $21 \pm 5^{\mathrm{a}, \mathrm{bA}}$ & $13 \pm 2^{\mathrm{aA}}$ & $0.019^{*}$ & $44 \pm 6^{\mathrm{b}}$ & $15 \pm 2^{\mathrm{aA}}$ & $19 \pm 3^{\mathrm{aA}}$ & $17 \pm 4^{\mathrm{aA}}$ & $17 \pm 4^{\mathrm{aA}}$ & $<0.001^{*}$ \\
\hline
\end{tabular}




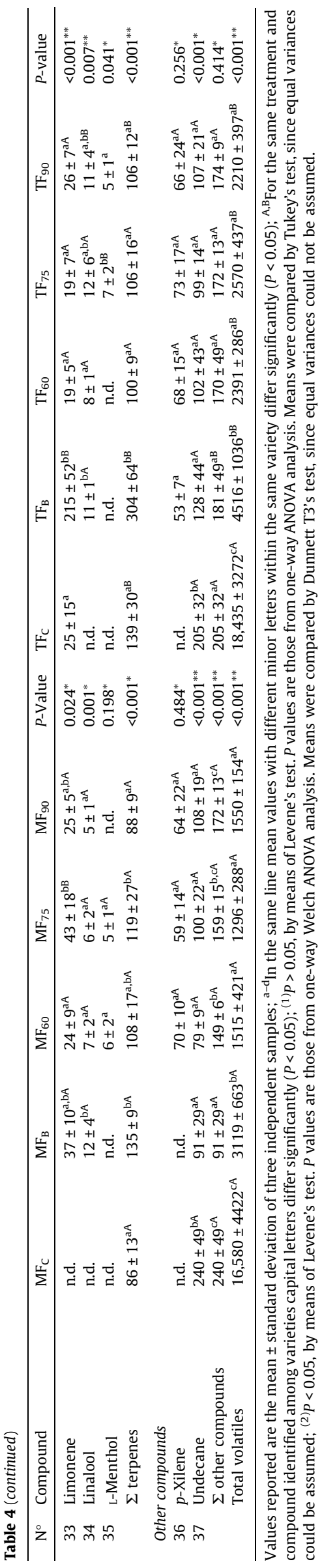

5-hepten-2-one, significant decreases in both varieties were reported when leaves were boiled. In MF, it was present at $358 \pm 177,318 \pm 182$ and $265 \pm 108 \mu \mathrm{g} 100 \mathrm{~g}^{-1}$ at 60,75 and $90 \mathrm{~min}$ of boiling respectively. Touriga Franca reported $559 \pm 90$, $689 \pm 180$ and $548 \pm 242 \mu \mathrm{g} 100 \mathrm{~g}^{-1}$ at 60,75 and 90 min of boiling respectively (Table 4 ). From blanching to $90 \mathrm{~min}$ of boiling, the losses of 6 -methyl-5-hepten-2-one were $82 \%$ in MF and $53 \%$ in TF. Therefore, 6-methyl-5-hepten-2-one is sensitive to boiling, and its reduction could be mainly related to the deterioration of lycopene, the substrate that yields 6-methyl-5-hepten-2-one (Kanasawud \& Crouzet, 1990). The presence of high amounts of 6-methyl-5-hepten-2-one is good for the overall aroma of grapevine leaves, since in other food products it is connoted with herbaceous and pungent sensations (Kraujalytè, Pelvan, \& Alasalvar, 2016; Wang et al., 2008). Therefore, a higher boiling period reduces the volatile sensations related to these descriptors, which is why the use of a lower boiling period is advisable.

Caryophyllene is a sesquiterpene with important biological properties (anticancerigenous, antioxidant, and antimicrobial) besides playing an important role in food, acting as an antifungal compound (Dahham et al., 2015). Caryophyllene reported low amounts during boiling in $\mathrm{MF}_{60}$ and $\mathrm{MF}_{75}$ min of boiling, with $12 \pm 9$ and $13 \pm 4 \mu \mathrm{g} 100 \mathrm{~g}^{-1}$ respectively. However, at $\mathrm{MF}_{90}$ this sesquiterpene reported similar values to those present in fresh leaves $\left(356 \pm 130\right.$ and $390 \pm 74 \mu \mathrm{g} 100 \mathrm{~g}^{-1}$ at $\mathrm{MF}_{\mathrm{C}}$ and $\mathrm{MF}_{90}$ respectively; Fig. 2 and Table 4). In TF, the caryophyllene pattern was completely different from MF. During boiling caryophyllene content was $544 \pm 198,489 \pm 189$ and $397 \pm 71 \mu \mathrm{g} 100 \mathrm{~g}^{-1}$ at $\mathrm{TF}_{60}, \mathrm{TF}_{75}$ and $\mathrm{TF}_{90}$ (Table 4). In fact, caryophyllene content in TF increased when leaves were blanched. The pattern observed in TF was also observed in pennyworth (Centella asiatica L.) juice, where caryophyllene is one of the major volatiles present (Apichartsrangkoon, Wongfhun, \& Gordon, 2009). Juice of pennyworth plants treated by high pressure increased the amounts of caryophyllene in $27 \%$, but the pasteurization process reduced this sesquiterpene content in 30\% (Apichartsrangkoon et al., 2009).

Therefore, for preservation purposes, grapevine leaves need to be blanched first and then boiled in order to become edible. Blanching and boiling periods are critical to the volatile fraction, in a way that $82 \%$ and $76 \%$ of the volatile content is reduced when MF and TF leaves are blanched, and when leaves are boiled, maximum losses of $92 \%\left(\mathrm{MF}_{75}\right)$ and $88 \%\left(\mathrm{TF}_{90}\right)$ are reported (Table 4$)$.

\section{Conclusions}

The culinary treatment applied to grapevine leaves caused severe changes in their appearance and chemical composition. The blanching and boiling processes led to color changes in the leaves, causing a loss of green coloration to a yellow-brownish coloration. Such loss of coloration was related to pigments, mainly chlorophylls. Chlorophylls content was drastically reduced mainly with boiling. Although carotenoids content was improved by blanching it was negatively affected by boiling. The GLV's were affected by blanching and mainly by boiling. Thermal treatments led to a loss of compounds related to green and cut-grass sensations, leading to the formation of other volatiles responsible for the herbaceous and woody sensations.

From the overall evaluation of the obtained data, so that grapevine leaves become edible they should be boiled for no longer that $60 \mathrm{~min}$ in order to avoid the loss of chemical components with important visual and sensory characteristics.

The use of these varieties for culinary preparation is also a good strategy to valorize this sub-product of the wine making industry as well as a possible revenue line for producers. 

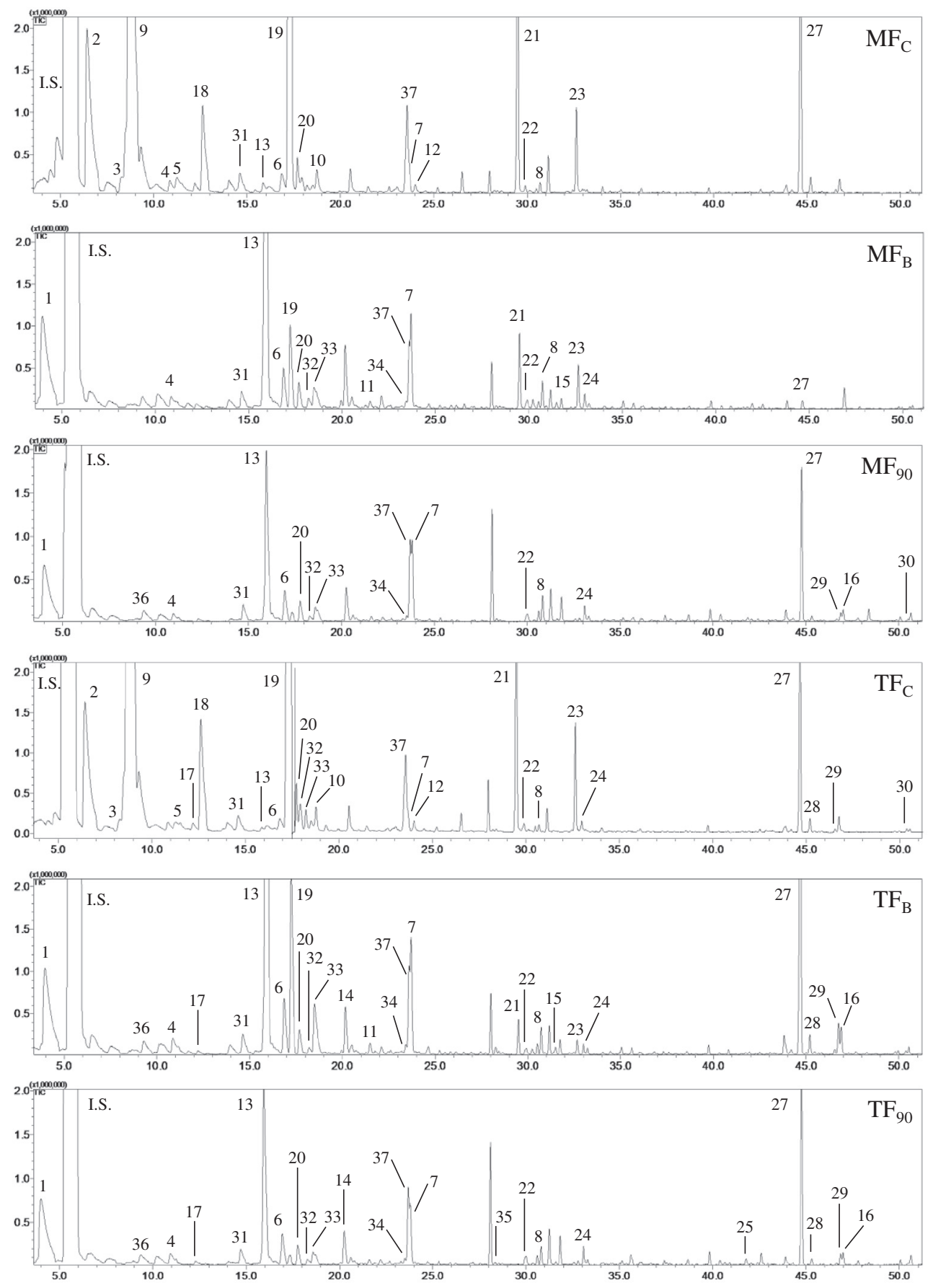

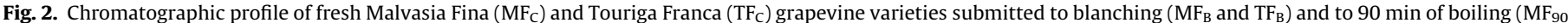
and $\mathrm{TF}_{90}$ ), obtained by HS-SPME using a DVB/CAR/PDMS fiber. Identification numbers correspond to those compounds listed in Table 4 (I.S. - internal standard).

\section{Acknowledgements}

The authors are grateful to PRODER (Programa de Desenvolvimento Rural) for the financial support under the project "Proteção da videira contra pragas e doenças em modo de produção biológico para obtenção de vinho biológico" ( $\left.n^{\circ} 47476\right)$.

\section{References}

Adebooye, O. C., Vijayalakshmi, R., \& Singh, V. (2008). Peroxidase activity, chlorophylls and antioxidant profile of two leaf vegetables (Solanum nigrum L. and Amaranthus cruentus L.) under six pretreatment methods before cooking. International Journal of Food Science E Technology, 43, 173-178.
Apichartsrangkoon, A., Wongfhun, P., \& Gordon, M. H. (2009). Flavor characterization of sugar-added pennywort (Centella asiatica L.) juices treated with Ultra-High Pressure and thermal processes. Journal of Food Science, 74, C643-C-646.

Bernhardt, S., \& Schlich, E. (2006). Impact of different cooking methods on food quality: Retention of lipophilic vitamins in fresh and frozen vegetables. Journal of Food Engineering, 77, 327-333.

Cremer, D. R., \& Eichner, K. (2000). Formation of volatile compounds during heating of spice paprika (Capsicum annuum) powder. Journal of Agricultural and Food Chemistry, 48, 2454-2460.

Dahham, S. S., Tabana, Y. M., Iqbal, M. A., Ahamed, M. B. K., Ezzat, M. O., Majid, A. S. A., \& Majid, A. M. S. A. (2015). The anticancer, antioxidant and antimicrobia properties of the sesquiterpene $\beta$-caryophyllene from the essential oil of Aquilaria crassna. Molecules, 20, 11808-11829.

Dinis, L.-T., Bernardo, S., Conde, A., Pimentel, D., Ferreira, H., Félix, L., \& MoutinhoPereira, J. (2016). Kaolin exogenous application boosts antioxidant capacity and 
phenolic content in berries and leaves of grapevine under summer stress. Journal of Plant Physiology, 191, 45-53.

Fernandes, F., Ramalhosa, E., Pires, P., Verdial, J., Valentão, P., Andrade, P., ... Pereira, J. A. (2013). Vitis vinifera leaves towards bioactivity. Industrial Crops and Products, 43, 434-440.

Goff, S. A., \& Klee, H. J. (2006). Plant volatile compounds: sensory cues for health and nutritional value? Science, 311, 815-819.

Gooch, J. W. (2011). Encyclopedic dictionary of polymers (2nd ed.). New York: Springer Science.

Hansen, M., Laustsen, A., Olsen, C., Poll, L., \& Sorensen, H. (1997). Chemical and sensory quality of broccoli (Brassica oleracea L. var Italica). Journal of Food Quality, 20, 441-459.

Hassan, M. N., Zainal, Z., \& Ismail, I. (2015). Green leaf volatiles: Biosynthesis, biological functions and their applications in biotechnology. Plant Biotechnology Journal, 13, 727-739.

Iyer, M. M., Sacks, G. L., \& Padilla-Zakour, O. I. (2010). Impact of harvesting and processing conditions on Green Leaf Volatile development and phenolics in concord grape juice. Journal of Food Science, 75, 297-304.

Kanasawud, P. \& Crouzet, J. C. (1990). Mechanism of formation of volatile compounds by thermal degradation of carotenoids in aqueous medium. 2 . Lycopene degradation. Journal of Agricultural and Food Chemistry, 38, $1238-1242$.

Kawashima, L. M., \& Soares, L. M. V. (2003). Mineral profile of raw and cooked leafy vegetables consumed in Southern Brazil. Journal of Food Composition and Analysis, 16, 605-611.

Kebede, B. T Grauwet, T Tabilo-Munizaga, G Palmers, S., Vervoort L, Hendrickx M., \& Loey, A. V. (2013). Headspace components that discriminate between thermal and high pressure temperature treated green vegetables: Identification and linkage to possible process-induced chemical changes. Food Chemistry, 141, 1603-1613.

Kraujalytè, V., Pelvan, E., \& Alasalvar, C. (2016). Volatile compound and sensory characteristics of various instant teas produced from black tea. Food Chemistry $194,864-872$.

Kumari, M., Gupta, S., Lakshmi, A. J., \& Prakash, J. (2004). Iron bioavailability in green leafy vegetables cooked in different utensils. Food Chemistry, 86, 217-222.

Lima, A., Bento, A., Baraldi, I., \& Malheiro, R. (2016). Selection of grapevine leaf varieties for culinary process based on phytochemical composition and antioxidant properties. Food Chemistry, 212, 291-295.

Luaces, P., Sanz, C., \& Pérez, A. G. (2007). Thermal stability of lipoxygenase and hydroperoxide lyase from olive fruit and repercussion on olive oil aroma biosynthesis. Journal of Agricultural and Food Chemistry, 55, 6309-6313.

Maiani, G., Castón, M. J. P., Catasta, G., Toti, E., Cambrodón, I. G., Bysted, A., .. Schlemmer, U. (2009). Carotenoids: actual knowledge on food sources, intakes, stability and bioavailability and their protective role in humans. Molecular Nutrition \& Food Research, 53, S194-S218.

Mayuoni-Kirshinbaum, L., \& Porat, R. (2014). The flavor of pomegranate fruit: A review. Journal of the Science of Food and Agriculture, 94, 21-27.

Miglio, C., Chiavaro, E., Visconti, A., Fogliano, V. \& Pellegrini, N. (2008). Effects of different cooking methods on nutritional and physicochemical characteristics of selected vegetables. Journal of Agricultural and Food Chemistry, 56, 139-147.

Negi, P. S., \& Roy, S. K. (2000). Effect of blanching and drying methods on $\beta$-carotene, ascorbic acid and chlorophyll retention of leafy vegetables. LWT-Food Science and Technology, 33, 295-298.

Nielsen, G. S., Larsen, L. M., \& Poll, L. (2004). Impact of blanching and packaging atmosphere on the formation of aroma compounds during long-term frozen storage of leek (Allium ampeloprasum Var. Bulga) slices. Journal of Agricultural and Food Chemistry, 52, 4844-4852.

Ozerol, N. H., \& Titus, J. F. (1965). The determination of total chlorophyll in methanol extracts. Transactions Illionois State Academy of Sciences, 58, 15-19.

Rudra, S. G., Sarkar, B. C., \& Shivhare, U. S. (2008). Thermal degradation kinetics of chlorophyll in pureed coriander leaves. Food and Bioprocess Technology, 1, 91-99.

Sánchez, C., Baranda, A. B., \& Marañón, I. M. (2014). The effect of High Pressure and High Temperature processing on carotenoids and chlorophylls content in some vegetables. Food Chemistry, 163, 37-45.

Sat, I. G., Sengul, M., \& Keles, F. (2002). Use of grape leaves in canned food. Pakistan Journal of Nutrition, 1, 257-262.

Steet, J. A., \& Tong, C. H. (1996). Degradation kinetics of green color and chlorophylls in peas by colorimetry and HPLC. Journal of Food Science, 61, 924-928.

Teixeira, A., Baenas, N., Dominguez-Perles, R., Barros, A., Rosa, E., Moreno, D. A., \& Garcia-Viguera, C. (2014). Natural bioactive compounds from winery byproducts as health promoters: A review. International Journal of Molecular Sciences, 15, 15638-15678.

Wang, L.-F., Lee, J.-Y., Chung, J.-O., Baik, J.-H., So, S., \& Park, S. K. (2008). Discrimination of teas with different degrees of fermentation by SPME-GC analysis of the characteristic volatile flavour compound. Food Chemistry, 109, 196-206.

Weemaes, C. A., Ooms, V., Van Loey, A. M., \& Hendrickx, M. E. (1999). Kinetics of chlorophyll degradation and color loss in heated broccoli juice. Journal of Agricultural and Food Chemistry, 47, 2404-2409.

Whitaker, B. D., \& Saftner, R. A. (2000). Temperature-dependent autoxidation of conjugated trienols from apple peel yields 6-methyl-5-hepten-2-one, a volatile implicated in induction of scald. Journal of Agricultural and Food Chemistry, 48, 2040-2043. 